\title{
Pengaruh Kompetensi, Independensi dan Pengalaman Kerja Auditor terhadap Kualitas Audit dengan Etika Auditor Sebagai Variabel Moderasi (Studi Empiris Kantor Akuntan Publik di Semarang, Solo dan Yogyakarta)
}

\author{
Risky Fitri Septiana*, Jaeni \\ Fakultas Ekonomika dan Bisnis, Universitas Stikubank (UNISBANK) Semarang \\ Jl. Kendeng V Bendan Ngisor, Semarang, Indonesia \\ *Correspondence e-mail: riskyfs9724@gmail.com
}

\begin{abstract}
Abstrak. Tujuan dari penelitian ini guna menganalisa etika auditor sebagai variabel moderasi mempengaruhi kompetensi, independensi dan pengalaman kerja terhadap kualitas audit pada kantor akuntan publik di Semarang, Solo dan Yogyakarta. Variabel yang digunakan ialah kompetensi, independensi dan pengalaman kerja sebagai variabel independen sementara itu variabel dependen ialah kualitas audit dan etika auditor sebagai variabel moderasi. Pada penelitian ini menggunakan kuesioner dalam pengumpulan data sebanyak 16 Kantor Akuntan Publik dengan sejumlah 101 responden yang digunakan sebagai sample. Teknik analisis data menggunakan teknik skala pengukuran, uji kelayakan data, uji asumsi klasik, analisis regresi linear berganda, uji moderated regression analysis, dan koefisien determinasi (R2). Hasil pada penelitian ini mengungkapkan bahwa kompetensi memiliki pengaruh signifikan pada kualitas audit, sementara itu independensi dan pengalaman kerja tidak berpengaruh pada kualitas audit. Etika auditor tidak dapat memoderasi pengaruh kompetensi, independensi dan pengalaman kerja terhadap kualitas audit.
\end{abstract}

Kata kunci: Etika Auditor; Independensi; Kompetensi; Kualitas Audit dan Pengalaman Kerja

\begin{abstract}
The purpose of this study is to analyze auditor ethics as a moderating variable affecting competence, independence and work experience on audit quality at public accounting firms in Semarang, Solo and Yogyakarta. The variables used are competence, independence and work experience as independent variables while the dependent variable is audit quality and auditor ethics as moderating variables. In this study using a questionnaire in data collection as many as 16 Public Accounting Firms with a number of 101 respondents used as samples. The data analysis technique used a measurement scale technique, data feasibility test, classical assumption test, multiple linear regression analysis, moderated regression analysis, and the coefficient of determination (R2). The results of this study reveal that competence has a significant effect on audit quality, while independence and work experience have no effect on audit quality. Auditor ethics cannot moderate the effect of competence, independence and work experience on audit quality.
\end{abstract}

Keywords: Alphabetically sorted; Auditor Ethics, Independence, Competence, Audit Quality and Work Experience

\section{PENDAHULUAN}

Permasalahan yang terjadi di Indonesia dalam turunnya kualitas audit menjadi sorotan masyarakat. Menurut DeAngelo (1981), menjelaskan bahwa joint probability merupakan bagian dari kualitas audit yang merupakan seorang auditor akan mendapatkan serta memberitahukan pelanggaran yang ada dalam sistem akuntansi. Audit yang berkualitas absolut diperlukan untuk melindungi kebutuhan publik. Masalahnya, perkembangan ekonomi berkepanjangan menggantung pada laporan keuangan perusahaan yang mampu melaksanakan tugas dengan baik. Audit yang berkualitas dapat pula meminimalisir kesalahan risiko pada suatu laporan keuangan. Dengan demikian, hal itu dapat menaikkan kredibilitas laporan keuangan. Pengertian kualitas audit merupakan hasil pemeriksaan laporan keuangan. Kualitas audit menggambarkan bagaimana auditor akan mendapatkan lalu mengungkapkan penyimpangan yang ditemuinya pada pengecekkan laporan keuangan (DeAngelo,1981).

Ikatan Akuntan Indonesia (IAI) menentukkan ketentuan audit bahwa ketentuan umum, ketentuan profesi lapangan dan ketentuan pelaporan. Dalam hal ini ketentuan umum adalah pandangan kualitas individu yang wajib dipunyai seseorang auditor yang mewajibkan auditor untuk mempunyai kemampuan serta melatih teknis yang layak ketika melakukan kebijakan audit. Sementara itu kegiatan dilapangan dan ketentuan laporan menentukan auditor untuk mengumpulkan informasi dan melakukan kegiatan lainnya yang dilakukan selama proses audit juga mengharuskan auditor untuk membuat hasil laporan atas laporan keuangan yang diaudit dengan totalitas.

Kualitas audit sering menjadi pandangan karena masih sering menemukan kecurangan. Peristiwa yang populer ketika terdapat penyelewengan dalam melaksanakan internal audit ialah pada permasalahan pencurian atau korupsi dana Citibank yang dilakukan oleh Melinda Dee, yang ketahuan mengalihkan sebagian dana nasabah secara memanipulasi tanda tangan nasabah pada lembar isian transfer, memanipulasi tanda tangan bertepatan pada 23 Desember 2010 terhadap pemeroleh PT. Abadi Agung Utama. Uang sebanyak 50.000.000 diterima Bank Artha Graha untuk uang muka pembelian 
3 unit lantai 33 combin. serta memakai nama serta tanda tangan tiruan nasabah-nasabahnya, Malinda Dee mengirimkan uang sebanyak Rp 250.000.000 pada lembar isian terhadap PT. Samudera Asia Nasional bertepatan pada 27 Desember 2010 serta sebanyak jumlah yang serupa bertepatan pada 26 Januari 2011 juga memalsukan dalam lembar isian pengiriman sebanyak Rp. 50.000 .000 bertepatan pada 28 Januari 2011.

Kualitas audit menjelaskan adanya peluang auditor mendapatkan kecurangan pada sistem akuntansi serta mencatatkan pada laporan keuangan yang diutarakan terhadap bagian manajemen. Auditor harus mampu menunjukan kecurangan itu pada laporan keuangan audit guna menjaga independensinya agar meningkat. Serta kemampuannya dengan teliti dan benar (Siahaan \& Simanjuntak, 2019). Kualitas audit berguna karena pada kualitas audit yang meningkat sehingga bisa menghasilkan laporan keuangan yang bisa dipercayai sebagai awal pengambilan keputusan. Etika sangat berkaitan dengan kompetensi, independensi dan pengalaman kerja. Auditor memiliki keharusan untuk meningkatkan ketentuan perilaku bermoral pada organisasi di mana auditor berlindung, pekerjaan auditor, masyarakat dan diri auditor sendiri. Dalam melakukan audit, akuntan publik harus berperan seperti seseorang yang mahir pada aspek akuntansi dan auditing. Pencapaian kemampuan sebagai seorang auditor, auditor wajib telah menerima pendidikan formal, melatih teknis yang dikembangkan dengan pengalaman pada praktik audit. Faktor penyebab kualitas audit itu baik pada penelitian ini yaitu kompetensi, independensi dan pengalaman kerja. Variabel moderasi pada penelitian ini merupakan etika auditor, yang bertujuan untuk memperkuat ataupun memperlemah pengaruh faktorfaktor yang mempengaruhi kompetensi, independensi dan pengalaman kerja.

\section{Kompetensi Terhadap Kualitas Audit}

Kompetensi merupakan kemampuan profesional yang dimiliki individu auditor dalam mengaplikasikan pengetahuannya untuk membereskan pekerjaan, baik dalam kelompok atau individu menurut Standar Profesional Akuntan Publik (SPAP), kode etik dan ketentuan hukum yang berstandar umum. Seorang auditor dapat disebut berkompeten jika waktu melaksanakan audit mempunyai keahlian untuk melakukan pekerjaan dengan ringan, gesit, perspektif, dan terlalu sedikit atau tidak pernah membuat kesalahan.

Dalam menjalankan pelatihan teknis yang telah dilakukan seorang auditor harus memiliki keterampilan yang mencakup beberapa aspek teknis dan formal. Berdasarkan teori agensi mengasumsikan bahwa auditor yang mempunyai pengetahuan ekstensif menjadi berkompeten dan menghasilkan kualitas audit yang baik. Apabila kompetensi seseorang itu semakin meningkat maka hasil pemeriksaan auditnya akan semakin meningkat pula. Hal ini diperkuat oleh Wardhani (2014) dan Harjanto (2014) menyatakan kompetensi berpengaruh positif signifikan terhadap kualitas audit. Hal ini berbanding terbalik terhadap penelitian Suharti \& Apriyanti (2019) dan Khurun In \& Asyik (2019) yang menjelaskan bahwa kompetensi tidak berpengaruh signifikan terhadap kualitas audit.

\section{Independensi Terhadap Kualitas Audit}

Independensi ialah kejujuran yang dipunyai diri auditor dalam menyatakan opini audit guna mempertimbangkan bukti dengan objektif serta tidak memihak yaitu disebut dengan independensi (Mulyadi, 2002). Independensi dari seorang auditor sangat berkaitan dengan Kualitas Audit. Semakin jujur dan tidak memihak seorang auditor maka semakin independensi. Meningkatnya independensi dari seorang auditor dapat disimpulkan akan meningkatkan pula kualitas audit dari seorang auditor.

Bersumber pada teori agensi mengasumsikan bahwa apabila seseorang auditor bersikap independen, dengan demikian auditor akan memberi evaluasi yang sebenar-benarnya pada laporan keuangan yang diselidiki, tanpa mempunyai tanggungan apapun oleh pihak manapun. Sehingga penilaiannya akan menggambarkan situasi yang sesungguhnya dari perusahaan yang akan diaudit. Dengan demikian agunan atas kekuatan laporan yang diberikan oleh auditor bisa dipercaya oleh pihak-pihak yang bersangkutan. Dengan itu intinya jika independensi seseorang itu semakin meningkat maka hasil pemeriksaan auditnya akan semakin meningkat pula. Hal ini diperkuat oleh Ardini (2010), Maulana (2020) dan Siahaan \& Simanjuntak (2019) dengan hasil penelitian bahwa kompetensi memiliki pengaruh positif terhadap kualitas audit. Hal ini berbanding terbalik dengan penelitian Suharti \& Apriyanti (2019) yang menyatakan Independensi tidak berpengaruh signifikan terhadap kualitas audit.

\section{Pengalaman Kerja Terhadap Kualitas Audit}

Auditor yang memiliki jam kerja yang lebih banyak atau dapat dikatakan berpengalaman akan mengajarkan kualitas audit yang lebih baik daripada auditor yang memiliki jam kerja atau pengalaman yang lebih sedikit. Hal ini karena kemampuan seseorang baik secara teknik maupun secara psikologis dapat membentuk pengalaman.

Berdasarkan dari teori agensi mengasumsikan bahwa karyawan yang mempunyai pengalaman kerja yang meningkat akan mempunyai kelebihan dalam menemukan kesalahan, mengartikan kesalahan, dan mengetahui pemicu munculnya kesalahan. Pada dasarnya pengalaman dapat menggambarkan situasi yang lebih berpengaruh bagi sebuah pekerjaan akuntan publik yang membutuhkan profesionalisme yang lebih tinggi, karena pengalaman yang semakin meningkat bisa mempengaruhi kualitas pekerjaan seorang auditor. Hal 
Risky Fitri Septiana dan Jaeni, Pengaruh Kompetensi, Independensi dan Pengalaman Kerja Auditor terhadap Kualitas Audit dengan Etika Auditor Sebagai Variabel Moderasi (Studi Empiris Kantor Akuntan Publik di Semarang, Solo dan Yogyakarta)

ini diperkuat oleh Puspita, Rupa \& Puspita Rini (2020), Sarca \& Rasmini (2019) dan Putri Erawan \& Sukartha (2018) atas hasil penelitian bahwa kualitas audit dipengaruhi oleh pengalaman kerja. Hal ini tidak sejalan oleh penelitian Janrosl (2017) yang mengungkapkan bahwa Pengalaman kerja tidak berpengaruh signifikan terhadap kualitas audit.

\section{Etika Auditor Memoderasi Pengaruh Kompetensi Terhadap Kualitas Audit.}

Menurut Alim, Hapsari \& Purwanti (2007) mengembangkan atribusi dalam kualitas audit yang salah satunya merupakan ketentuan etika yang meningkat sementara itu ciri-ciri lainnya adalah kompetensi auditor. Berdasarkan teori agensi mengasumsikan bahwa apabila etika auditor itu baik dan sesuai dengan ketentuan yang ditetapkan sehingga kompetensi akan meningkat dan kualitas auditor juga akan meningkat. Hal tersebut disebabkan etika yang dipunyai pada auditor akan berhubungan langsung terhadap klien. Hal ini diperkuat oleh Suharti \& Apriyanti (2019), Mutiara (2018) dan Mariyanto (2017) menyatakan bahwa kompetensi berpengaruh positif signifikan terhadap kualitas audit dengan etika auditor sebagai variabel moderasi. Hal ini berbanding terbalik dengan penelitian Kharismatuti \& P. Basuki (2012) menyimpulkan bahwa kompetensi tidak berpengaruh signifikan terhadap kualitas audit dengan etika auditor sebagai variabel moderasi.

\section{Etika Auditor Memoderasi Pengaruh Independensi Terhadap Kualitas Audit.}

Menurut Alim, Hapsari \& Purwanti (2007) mengungkapkan bahwa apabila manajemen dan auditor tidak mencapai kesepakatan, maka hal itu dapat memaksa auditor untuk bertindak diluar ketentuan termasuk dalam pemberian pendapat. Keahlian auditor akan bertahan dalam tekanan klien tergantung pada etika profesional yang dimiliki.

Berdasarkan dari teori agensi mengasumsikan bahwa hal ini apabila etika auditor itu efektif dan sesuai pada ketentuan yang diresmikan maka independensi akan meningkat dan kualitas auditor juga akan meningkat. Jika auditor tidak dapat bertahan atas tuntutan klien tersebut maka dari itu dapat mengakibatkan independensi mereka melemah. Auditor diharuskan untuk memenuhi keinginan klien dikarenakan kedudukan auditor itu sangat sulit akan tetapi di satu sisi tindakan auditor bisamenjadi pelanggaran terhadap ketentuan profesi sebagai referensi kerja auditor.

Hal ini diperkuat oleh Mutiara (2018), Mariyanto (2017) dan Setiarini (2018) menyimpulkan bahwa independensi yang dimoderasi oleh etika auditor berpengaruh signifikan oleh kualitas audit. Hal ini berbanding terbalik dengan penelitian Suharti \& Apriyanti (2019) menyimpulkan bahwa independensi tidak berpengaruh signifikan terhadap kualitas audit dengan etika auditor sebagai variabel moderasi.

\section{Etika Auditor Memoderasi Pengaruh Pengalaman Kerja Terhadap Kualitas Audit.}

Semakin bertambahnya waktu pengalaman kerja yang dipunyai oleh auditor maka perilaku yang dipunyai oleh auditor akan lebih etis dibandingkan dengan auditor yang memiliki pengalaman kerja yang lebih minim. Pengalaman kerja dapat dipengaruhi keahlian auditor dalam melihat adanya penyimpangan terhadap perusahaan yang sebagai kliennya serta pelatihan yang dilaksanakan dapat menaikkan kemampuan akuntan publik saat melakukan audit. Kemampuan auditor dapat dipengaruhi pengalaman kerja dalam mendeteksi kekeliruan yang ada pada suatu perusahaan atau kliennya. Dalam melaksanakan audit, keahlian auditor atau akuntan publik dapat ditingkatkan dengan cara pelatihan.

Berdasarkan teori agensi mengasumsikan bahwa apabila etika auditor itu baik dan tepat dengan ketentuan yang disahkan maka pengalaman kerja akan meningkat dan kualitas auditor juga akan meningkat, tetapi semakin rendah seorang auditor menaati etika auditor yang sudah disahkan maka akan semakin rendah pula kualitas audit yang diwujudkan. Hal ini diperkuat oleh Sarca \& Rasmini (2019) oleh menyimpulkan bahwa pengalaman kerja yang dimoderasi oleh etika auditor berpengaruh positif signifikan terhadap kualitas audit. Hal ini berbanding terbalik dengan penelitian Kusuma Herawati \& Yunilma (2020) menyimpulkan bahwa pengalaman kerja yang dimoderasi oleh etika auditor tidak berpengaruh signifikan terhadap kualitas audit.

\section{Definisi Operasional dan Pengukuran Variabel}

1. Kompetensi Auditor (X1) merupakan sesuatu yang dimiliki seorang auditor atau akuntan publik dalam melaksanakan audit dengan baik. Variabel ini dinilai menggunakan pengukuran skala likert 4 (empat) point dari sangat tidak setuju sampai dengan sangat setuju.

2. Independensi (X2) merupakan suatu kedudukan atau kondisi yang menjelaskan dimana auditor tidak teribat dengan aspek manapun. Variabel ini dinilai menggunakan pengukuran skala likert likert 4 (empat) point dari sangat tidak setuju sampai dengan sangat setuju.

3. Pengalaman kerja (X3) merupakan suatu pemahaman, kemahiran, dan keahlian yang harus dipunyai setiap karyawan dalam melaksanakan tanggungjawab dari tugas yang telah diberikan. Variabel ini dinilai dengan pengukuran skala likert 4 (empat) point dari sangat tidak setuju sampai dengan sangat setuju.

4. Etika Auditing (Z) merupakan suatu sikap, perilaku serta norma kehidupan yang berlaku pada suatu proses yang konstan untuk mendapatkan serta 
Risky Fitri Septiana dan Jaeni, Pengaruh Kompetensi, Independensi dan Pengalaman Kerja Auditor terhadap Kualitas Audit dengan Etika Auditor Sebagai Variabel Moderasi (Studi Empiris Kantor Akuntan Publik di Semarang, Solo dan Yogyakarta)

memperhitungkan bukti-bukti secara rasional. Variabel ini diukur dengan pengukuran likert 4 (empat) point dari sangat tidak setuju sampai dengan sangat setuju.

5. Kualitas audit (Y) bertujuan untuk menilai baik ataupun tidak baiknya suatu pengecekan yang dilaksanakan oleh auditor. Variabel ini diukur dengan pengukuran skala likert 4 (empat) point dari sangat tidak setuju sampai dengan sangat setuju.

\section{MODEL PENELITIAN}

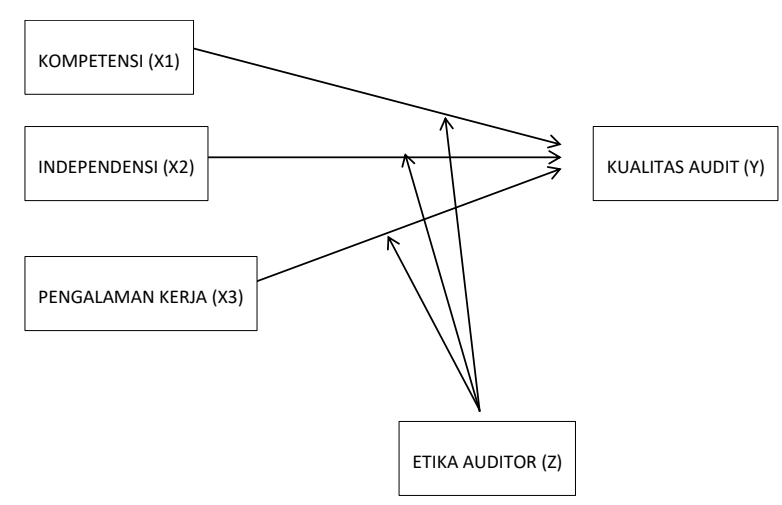

Keterangan:

$\mathrm{X} 1=$ Kompetensi

$\mathrm{X} 2=$ Independensi

$\mathrm{X} 3=$ Pengalaman Kerja

$\mathrm{Y} \quad=$ Kualitas Audit

$\mathrm{Z} \quad=$ Etika Auditor

\section{METODE}

Penelitian kuantitatif ialah jenis penelitian yang dilakukan dalam penelitian ini.

\section{Populasi dan Sampel}

Populasi pada penelitian ini merupakan seluruh auditor Kantor Akuntan Publik di Semarang, Solo, dan Yogyakarta yang tercantum pada IAPI (Ikatan Akuntan Publik Indonesia). Sampel dalam penelitian ini ialah auditor Kantor Akuntan Publik (KAP) di Semarang, Solo, dan Yogyakarta yang bersedia berperan sebagai objek penelitian.

Pada penelitian ini pengambilan sampel menggunakan teknik convenience sampling, yang mana metode pengambilan sampel harus layak atas tuntutan atau kualifikasi sampel pada populasi tertentu yang paling mudah diperoleh. Intinya populasi pada penelitian ini ialah Auditor pada Kantor Akuntan Publik (KAP) di Semarang, Solo dan Yogyakarta yakni sebanyak 101 orang.

\section{Jenis Data}

Pada penelitian ini memakai jenis data yang berupa data primer. Sumber data pada penelitian ini adalah Kuesioner yang disebarkan berupa daftar pernyataan tertulis kepada responden.

\section{Teknik Pengumpulan Data}

Akumulasi atau pengumpulan data pada penelitian ini menggunakan metode survei dengan instrumen kuesioner, yaitu dengan cara memberikan kumpulankumpulan pertanyaan ataupun pernyataan tertulis kepada responden guna mendapatkan jawaban (Sugiyono, 2017). Data tersebut didapatkan pada studi Kantor Akuntan Publik di Semarang, Solo dan Yogyakarta. Dan untuk mengolah data menggunakan software SPSS versi 21.

\section{HASIL DAN PEMBAHASAN Analisis Statistik}

Statistik deskriptif pada penelitian ini dapat diaplikasikan untuk memperoleh informasi mengenai karater variabel-variabel penelitian, diantaranya nilai minimum, maksimum, rata-rata (mean), dan akar kuadrat varian (standar deviasi). Nilai diperlukan untuk membuktikan rata-rata pada setiap variabel. Standar deviasi diperlukan untuk membuktikan data tersebut heterogen atau homogen. Nilai minimum diperlukan untuk membuktikan nilai terkecil dari setiap variabel. Nilai maksimum diperlukan untuk membuktikan nilai tertinggi dari setiap variabel. (Ghozali, 2016).

Tabel 1. Uji Analisis Statistik

\begin{tabular}{llllll}
\hline & $\mathrm{N}$ & Min & Max & Mean & Std. Deviation \\
\hline $\mathrm{X} 1$ & 101 & 19 & 28 & 23,85 & 2,206 \\
\hline $\mathrm{X} 2$ & 101 & 8 & 25 & 15,05 & 4,272 \\
\hline $\mathrm{X} 3$ & 101 & 17 & 28 & 24,56 & 2,677 \\
\hline $\mathrm{Y} 1$ & 101 & 35 & 55 & 47,57 & 4,462 \\
\hline $\mathrm{Z} 1$ & 101 & 32 & 48 & 40,35 & 4,004 \\
\hline $\begin{array}{l}\text { Valid N } \\
\text { (listwise) }\end{array}$ & 101 & & & & \\
\hline
\end{tabular}

Sumber : data primer 2021

1. Kompetensi memiliki 7 butir pernyataan dengan nilai minimum 1 dan nilai maximum 4. Untuk variabel kompetensi dapat diketahui nilai mean sebesar 23,85 dan standar deviasi senilai 2,206 yang mana nilainya lebih rendah dari nilai rata-rata. Artinya, nilai ratarata menjelaskan representasi yang baik dari kelengkapan data. Sementara itu pada tabel nilai minimum dapat dilihat jawaban sangat tidak setuju sebanyak 18 responden dan jawaban sangat setuju sebanyak sebanyak 28 responden.

2. Independensi memiliki 6 butir pertanyaan dengan nilai minimum 1 dan nilai maximum 4. Untuk variabel independensi dapat diketahui nilai mean sebesar 15,05 dan standar deviasi senilai 4,272 yang mana nilainya lebih rendah dari nilai rata-rata. Artinya, nilai rata-rata menjelaskan representasi yang baik dari kelengkapan data. Sementara itu pada tabel nilai minimum dapat dilihat jawaban sangat tidak setuju sebanyak 8 dan jawaban sangat setuju sebanyak 28 responden. 
Risky Fitri Septiana dan Jaeni, Pengaruh Kompetensi, Independensi dan Pengalaman Kerja Auditor terhadap Kualitas Audit dengan Etika Auditor Sebagai Variabel Moderasi (Studi Empiris Kantor Akuntan Publik di Semarang, Solo dan Yogyakarta)

3. Pengalaman kerja memiliki 7 butir pertanyaan dengan nilai minimum 1 dan nilai maximum 4 . Untuk variabel independensi dapat diketahui nilai mean sebesar 24,56 dan standar deviasi senilai 2,677 yang mana nilainya lebih rendah dari nilai rata-rata. Artinya, nilai rata-rata menjelaskan representasi yang baik dari kelengkapan data. Sementara itu pada tabel nilai minimum dapat dilihat jawaban sangat tidak setuju sebanyak 17 responden dan jawaban sangat setuju sebanyak 28 responden.

4. Kualitas audit memiliki 13 butir pertanyaan dengan nilai minimum 1 dan nilai maximum 4 . Untuk variabel independensi dapat diketahui nilai mean sebesar 47,57 dan standar deviasi senilai 4,462 yang mana nilainya lebih rendah dari nilai rata-rata. Artinya, nilai rata-rata menjelaskan representasi yang baik dari kelengkapan data. Sementara itu pada tabel nilai minimum dapat dilihat jawaban sangat tidak setuju sebanyak 35 responden dan jawaban sangat setuju sebanyak 55 responden.

5. Etika auditor memiliki 12 butir pertanyaan dengan nilai minimum 1 dan nilai maximum 4. Untuk variabel independensi dapat diketahui nilai mean sebesar 40,35 dan standar deviasi senilai 4,004 yang mana nilainya lebih rendah dari nilai rata-rata. Artinya, nilai rata-rata menjelaskan representasi yang baik dari kelengkapan data. Sementara itu pada tabel nilai minimum dapat dilihat jawaban sangat tidak setuju sebanyak 32 responden dan jawaban sangat setuju sebanyak 48 responden.

\section{Uji Normalitas}

Tabel 2. Uji Normalitas

\begin{tabular}{|l|l|l|l|}
\hline $\begin{array}{l}\text { Kolmogorov- } \\
\text { Smirnov Z }\end{array}$ & Asymp.Sig. & Standar & Keputusan \\
\hline 1,132 & 0,154 & $>0,05$ & Normal \\
\hline
\end{tabular}

Sumber : data primer 2021

Dapat dilihat pada tabel 2 pengujian normalitas, peneliti ini memakai uji Kolmogorov Smirnov (K-S), menunjukkan perolehan uji normalitas, dapat diketahui bahwa nilai Asymp.Sig. sebesar $0,154>\alpha(0,05)$. Berdasarkan hal tersebut, data yang digunakan telah berdistribusi normal serta sudah mencukupi uji asumsi normalitas.

\section{Uji Multikolinearitas}

Tabel 3. Uji Multikolinearitas

\begin{tabular}{lccc}
\hline \multicolumn{1}{c}{ Variabel } & Tolerance & VIF & Kesimpulan \\
\hline Kompetensi & 0,723 & 1,383 & Tidak terjadi \\
$\begin{array}{l}\text { Independensi } \\
\begin{array}{l}\text { Pengalaman } \\
\text { kerja }\end{array}\end{array}$ & 0,835 & 1,198 & Tidak terjadi \\
& 0,472 & 2,117 & Tidak terjadi \\
\hline
\end{tabular}

Sumber : data primer 2021
Berdasarkan tabel 3 menunjukkan nilai tolerance variabel independen tidak ada yang kurang 0,10 . Pada variabel kompetensi nilai tolerance senilai $0,723>0,10$; variabel independensi nilai tolerance senilai $0,835>$ 0,10 ; dan variabel pengalaman kerja nilai tolerance senilai $0,472>0,10$.

Hal ini sama dengan terjadi pada nilai Variance Inflation Factor (VIF). Dapat dilihat bahwa masingmasing nilai Variance Inflation Factor (VIF) pada variabel independen tidak ada yang lebih dari 10. Pada variabel kompetensi nilai VIF sebesar $1,383<10$; variabel independensi nilai VIF senilai 1,198; dan variabel pengalaman kerja nilai VIF senilai 2,117. Dapat diartikan bahwa model regresi pada penelitian ini tidak ditemukan masalah multikolinearitas antar variabel independen.

\section{Uji Heteroskedastisitas}

Tabel 4. Uji Heteroskedastisitas

\begin{tabular}{lccc}
\hline \multicolumn{1}{c}{ Variabel } & Sig & Standar & Kesimpulan \\
\hline Kompetensi &, 312 & $>0,05$ & $\begin{array}{c}\text { Tidak } \\
\text { terjadi }\end{array}$ \\
Independensi &, 699 & $>0,05$ & Tidak terjadi \\
Pengalaman kerja &, 404 & $>0,05$ & Tidak terjadi \\
Etika_Kompetensi &, 228 & $>0,05$ & Tidak terjadi \\
Etika_Independensi &, 597 & $>0,05$ & Tidak terjadi \\
Etika_Pengalaman &, 329 & $>0,05$ & Tidak terjadi \\
\hline Sumber: data pimer
\end{tabular}

Sumber : data primer 2021

Berdasarkan tabel 4 mengungkapkan variabelvariabel dari penelitian ini mempunyai probabilitas signifikansi diatas tingkat kepercayaan $5 \%$ atau 0,05 . Jadi dapat disimpulkan bahwa pada penelitian ini tidak mengandung adanya heteroskedastisitas.

\section{Uji Determinasi $\left(\mathbf{R}^{2}\right)$}

Koefisien determinasi adalah seberapa besar kemampuan semua variabel independen dalam menunjukkan varian dari variabel dependennya. Nilai koefisien determinasi ialah antara nol dan satu.

Tabel 5. Uji Determinasi $\left(\mathrm{R}^{2}\right)$

\begin{tabular}{ccccc}
\hline Model & $\mathrm{R}$ & $\begin{array}{c}\mathrm{R} \\
\text { Square }\end{array}$ & $\begin{array}{c}\text { Adjusted } \\
\text { R Square }\end{array}$ & $\begin{array}{l}\text { Std. Error of } \\
\text { the Estimate }\end{array}$ \\
\hline 1 &, $839^{\mathrm{a}}$ &, 705 &, 686 & 2,501 \\
\hline Sumber: data primer 2021 & &
\end{tabular}

Berdasarkan tabel 5 menunjukkan bahwa nilai Adjusted $R$ Square senilai 0,686 ataupun 68,6\%. Artinya variabel kualitas audit bisa dijelaskan oleh variabel kompetensi, independensi, dan pengalaman sebesar $68,6 \%$, sedangkan sisanya $31,4 \%$ dipengaruhi faktor lain diluar model.

\section{Uji Simultan (uji F)}

Uji $F$ berguna untuk mengetahui apakah terdapat hubungan antara variabel independen dengan variabel dependen secara bersama-sama (Ghozali, 2016). Untuk 
Risky Fitri Septiana dan Jaeni, Pengaruh Kompetensi, Independensi dan Pengalaman Kerja Auditor terhadap Kualitas Audit dengan Etika Auditor Sebagai Variabel Moderasi (Studi Empiris Kantor Akuntan Publik di Semarang, Solo dan Yogyakarta)

melihat nilai signifikan dari uji $\mathrm{F}$ dilihat pada output hasil regresi dengan signifikansi atau derajat kepercayaan $0,05(5 \%)$.

Tabel 6. Uji F

\begin{tabular}{|l|c|c|c|c|c|}
\hline \multicolumn{1}{|c|}{ Model } & $\begin{array}{c}\text { Sum of } \\
\text { Squares }\end{array}$ & Df & $\begin{array}{c}\text { Mean } \\
\text { Square }\end{array}$ & F & Sig. \\
\hline Regression & 1402,647 & 6 & 233,775 & 37,369 &, $000^{\mathrm{a}}$ \\
\hline Residual & 588,046 & 94 & 6,256 & & \\
\hline Total & 1990,693 & 100 & & & \\
\hline \multicolumn{7}{|l|}{ Sumber: Hasil Data Penelitian, 2021 } \\
\hline
\end{tabular}

Tabel 7. Uji t hipotesis

\begin{tabular}{lrrrrrr}
\hline \multirow{2}{*}{ Model } & \multicolumn{2}{c}{ Unstandardized Coefficients } & Standardized Coefficients & & \\
\cline { 2 - 5 } & \multicolumn{1}{c}{$\mathrm{B}$} & Std.Error & Beta & \multicolumn{1}{c}{ T } & Sig. \\
\hline (Constant) & $-273,107$ & 125,731 & & $-2,172$ &, 032 \\
\hline Kompetensi & 43,311 & 19,578 &, 645 &,- 490 & 2,212 &, 029 \\
\hline Independensi &,- 446 & 24,282 &,- 725 &,- 691 &, 491 \\
\hline Pengalaman Kerja & $-28,465$ &, 020 & $-1,270$ & $-1,840$ &, 069 \\
\hline Etika_Kompetensi &,- 036 &, 016 &, 310 &, 499 &, 619 \\
\hline Etika_Independensi &, 008 & 23,650 & 1,962 & 1.912 &, 059 \\
\hline Etika_pengalaman & 45,217 & & & &
\end{tabular}

Sumber: data primer 2021

1. Pengaruh Kompetensi terhadap Kualitas Audit.

Berdasarkan tabel 7 menunjukkan kompetensi secara parsial berpengaruh signifikan terhadap kualitas audit sehingga hipotesis pertama (H1) diterima. Hal ini menjelaskan bahwa kompetensi berpengaruh positif signifikan terhadap kualitas audit. Dengan demikian, hipotesis yang menyatakan bahwa komepetensi berpengaruh positif signifikan terhadap kualitas audit diterima. Semakin tinggi kompetensi maka dapat meningkatkan kualitas audit. Hal ini sejalan dengan penelitian Wardhani (2014) dan Harjanto (2014) menyatakan kompetensi berpengaruh positif signifikan terhadap kualitas audit.

2. Pengaruh Independensi terhadap Kualitas Audit.

Berdasarkan tabel 7 menunjukkan independensi secara langsung tidak ada pengaruh yang signifikan terhadap kualitas audit sehingga hipotesis kedua (H2) ditolak. Hal ini menunjukan bahwa independensi tidak berpengaruh signifikan terhadap kualitas audit. Kualitas audit tidak dipengaruhi oleh tinggi atau rendahnya independensi. Pernyataan ini sama dengan penelitian Suharti \& Apriyanti (2019) yang menyatakan Independensi tidak berpengaruh signifikan terhadap kualitas audit.

3. Pengaruh Pengalaman Kerja terhadap Kualitas Audit. Berdasarkan tabel 7 menunjukkan pengalaman kerja secara langsung tidak ada pengaruh yang signifikan terhadap kualitas audit sehingga hipotesis ketiga (H3) ditolak. Pernyataan ini menyimpulkan bahwa pengalaman kerja tidak berpengaruh signifikan terhadap kualitas audit. Pernyataan ini serupa oleh penelitian Janrosl (2017) yang mengemukakan bahwa
Berdasarkan tabel 6 menunjukkan nilai $\mathrm{F}$ sebesar 37,369 dengan sig $0,000<0,05$. Dalam uji ini menunjukkan bahwa variabel kompetensi, independensi dan pengalaman secara simultan berpengaruh terhadap kualitas audit, sehingga jenis penelitian ini layak atau fit.

\section{Uji Hipotesis (Uji t)}

Uji hipotesis $t$ menggunakan guna mengenali kemampuan pada variabel independen secara individu untuk mengartikan karakter variabel dependen. Pengujian dilakukan dengan menggunakan tingkat signifikansi $0,05(\alpha=5 \%)$. 
Risky Fitri Septiana dan Jaeni, Pengaruh Kompetensi, Independensi dan Pengalaman Kerja Auditor terhadap Kualitas Audit dengan Etika Auditor Sebagai Variabel Moderasi (Studi Empiris Kantor Akuntan Publik di Semarang, Solo dan Yogyakarta)

menjelaskan bahwa meningkatnya etika auditor tidak dapat menguatkan maupun memperlemah kualitas audit ketika pengalaman kerja meningkat sehingga hipotesis keenam (H6) ditolak. Hal ini sejalan dengan penelitian Kusuma, Herawati \& Yunilma (2020) menyimpulkan bahwa etika auditor tidak dapat memoderasi pengaruh pengalaman kerja auditor terhadap kualitas audit.

\section{SIMPULAN}

Menurut hasil pada penelitian ini menunjukkan hasil antara lain:

1. Kompetensi auditor mempengaruhi positif signifikan terhadap Kualitas Audit pada Kantor Akuntan Publik di Kota Semarang, Solo dan Yogyakarta.

2. Independensi auditor tidak mempengaruhi terhadap Kualitas Audit pada Kantor Akuntan Publik di Kota Semarang, Solo dan Yogyakarta.

3. Pengalaman Kerja auditor tidak berpengaruh terhadap Kualitas Audit pada Kantor Akuntan Publik di Kota Semarang, Solo dan Yogyakarta.

4. Etika Auditor tidak dapat memoderasi pengaruh Kompetensi terhadap kualitas audit pada Kantor Akuntan Publik di Kota Semarang, Solo dan Yogyakarta.

5. Etika Auditor tidak dapat memoderasi pengaruh Independensi terhadap kualitas audit pada Kantor Akuntan Publik di Kota Semarang, Solo dan Yogyakarta.

6. Etika Auditor tidak dapat memoderasi pengaruh Pengalaman Kerja terhadap kualitas audit pada Kantor Akuntan Publik di Kota Semarang, Solo dan Yogyakarta.

\section{DAFTAR PUSTAKA}

Alim, M. N., Hapsari, T., \& Purwanti, L. (2007, Juli 2628). Pengaruh Kompetensi dan Independensi terhadap Kualitas Audit dengan Etika Auditor sebagai Variabel Moderasi. Simposium Nasional Akuntansi X.

Ardini, L. (2010). Pengaruh Kompetensi, Independensi, Akuntanbilitas dan Motivasi terhadap Kualitas Audit. Jurnal Ekonomi dan Bisnis Airlangga, 20(3), 329-349.

DeAngelo, L. E. (1981). Auditor Size and Audit Quality. Journal of Accounting and Economics, 3(3), 183199.

Ghozali, I. (2016). Aplikasi Analisis Multivariete dengan program IBM SPSSS 23. Semarang: BP Universitas Diponegoro.

Harjanto, A. P. (2014). Pengaruh Kompetensi, Independensi, Objektivitas, Akuntanbilitas dan Integritas terhadap Kualitas Audit dengan Etika Auditor sebagai Variabel Moderasi (Studi Empiris KAP di Semarang). Universitas Diponegoro.

Janrosl, V. S. (2017). Pengaruh Akuntabilitas, Independensi, Pengalaman Kerja dan Standart
Audit terhadap Kualitas Audit pada KAP Batam. EKOBISTEK, 6(1), 156-163.

Kharismatuti, N., \& P. Basuki, H. (2012). Pengaruh Kompetensi dan Independensi terhadap Kualitas Audit dengan Etika Auditor sebagai Variabel Moderasi. Diponegoro Journal of Accounting, l(1), 1-10.

Khurun In, A. W., \& Asyik, N. F. (2019, Agustus). Pengaruh Kompetensi dan Independensi terhadap Kualitas Audit dengan Etika Auditor sebagai Variabel Pemoderasi. Jurnal Ilmu dan Riset Akuntansi (JIRA), 8(8).

Kusuma, E. N., Herawati, \& Yunilma. (2020, November). Pengaruh Profesionalisme, Independensi dan Pengalaman Kerja terhadap Kualitas Audit dengan Etika Profesi sebagai Variabel Moderasi (Studi empiris pada KAP di Padang dan Pekanbaru 2020). E jurnal Bung Hatta, 17(1).

Mariyanto, B. F. (2017). Pengaruh Kompetensi dan Independensi terhadap Kualitas Audit dengan Etika Auditor sebagai Variabel Moderasi. Jurnal Ilmu dan Riset Akuntansi (JIRA), 6(2), 761-779.

Maulana, D. (2020). Pengaruh Kompetensi, Etika dan Integritas Auditor terhadap Kualitas Audit. Jurnal Ilmiah Indonesia, 5(1), 39-53.

Mulyadi. (2002). Auditing (Edisi kelima ed.). Jakarta: Salemba Empat.

Mutiara, I. (2018). Pengaruh Kompetensi dan Independensi Auditor terhadap Kualitas Audit dengan Etika Auditor sebagai Variabel Moderasi. Jurnal Riset Akuntansi Jambi, 1(2), 33-39.

PD Sugiyono. (2017). Metode Penelitian Bisnis Pendekatan Kuantitatif dan Kualitatif dan $R \& D$. Bandung: CV Alfabeta.

Puspita, P. R., Rupa, I. W., \& Saputra Rini , I. A. (2020). Pengaruh Pengalaman Kerja, Independensi, Kompetensi Auditor terhadap Kualitas Audit pada BPK RI Perwakilan Provinsi Bali. Jurnal Riset Akuntansi Warmadewa, 1(1), 29-33.

Putri Erawan, N. A., \& Sukartha, I. M. (2018, September). Pengaruh Kompetensi, Pengalaman Kerja, Gaya Kepemimpinan dan Lingkungan Kerja pada Kualitas Audit. E Jurnal Akuntansi, 24(3), 2360-2388.

Sarca, P. N., \& Rasmini, N. K. (2019, Maret). Pengaruh Pengalaman Auditor dan Independensi pada Kualitas Audit dengan Etika Auditor sebagai Variabel Moderasi . E Jurnal Akuntansi, 26(3), 2240-2267.

Setiarini, J. (2018). Pengaruh Kompetensi dan Independensi terhadap Kualitas Audit dengan Etika Auditor sebagai Variabel Moderasi. Jurnal Ilmu dan Riset Akuntansi, 7(4).

Siahaan , S. B., \& Simanjuntak, A. (2019). Pengaruh Kompetensi Auditor, Independensi Auditor,Integritas Auditor dan Profesionalisme 
Risky Fitri Septiana dan Jaeni, Pengaruh Kompetensi, Independensi dan Pengalaman Kerja Auditor terhadap Kualitas Audit dengan Etika Auditor Sebagai Variabel Moderasi (Studi Empiris Kantor Akuntan Publik di Semarang, Solo dan Yogyakarta)

Auditor terhadap Kualitas Audit dengan Etika Auditor sebagai Variabel Moderasi (Studi Kasus Pada Kantor Akuntan Publik Di Kota Medan). Jurnal Manajemen, 5(1), 81 - 92.

Suharti, \& Apriyanti, T. (2019, Juni). Pengaruh Kompetensi dan Independensi terhadap Kualitas Audit dengan Etika Auditor sebagai Variabel Moderasi. BILANCIA Jurnal Ilmiah Akuntansi, 3(2), 208-217.

Wardhani, V. K. (2014, Januari). Independensi, Integritas, Obyektivitas dan Kompetensi terhadap Kualitas Audit. The Journal of Innovation in Business and Economics (JIBE), 5(1), 63 - 74. 